\title{
15 MYTHS ABOUT MARKET VALUE
}

\author{
Ewa Kucharska - Stasiak, prof., Ph.D. \\ Department of Investment and Real Estate \\ University of Lodz \\ e-mail:ewkuchar@uni.lodz.pl
}

\begin{abstract}
Market value is one of the most difficult notions in economics. It is also one of the most puzzling in the valuation industry, although its definitions can be found in the International Valuation Standards, European Valuation Standards, RICS standards and national standards. This value tends to be given different interpretations and misconceptions surrounding it are shared by many members of the property valuer community. The many ways in which property market value is understood leads to misvaluations and significant variations between valuation results, which are damaging to the prestige of the property valuation profession.

This article explores areas giving rise to the misinterpretations of property market value to provide a critical review of the existing views, and to put forward arguments explaining why they should be revised. To this end, a critical literature review and observations made by the author during discussions with valuation professionals taking skill-improvement courses, scientific conferences on valuation methodology and practice, and entry exams for the profession of property valuers are used.

Three main areas conducive to the emergence of myths have been identified: the interpretation of property market value (four myths), the process of arriving at property market value (ten myths) and the interpretation of valuation results (one myth). The myths are challenged on the grounds of the market value concept and its interpretation as used in economics.
\end{abstract}

Keywords: market value, market value interpretation, property value.

JEL Classification: $R 39, D 46$.

Citation: Kucharska - Stasiak E., 2018, The 15 Myths About Market Value, Real Estate Management and Valuation, vol. 26, no. 3, pp. 113-121.

DOI: $10.2478 /$ remav-2018-0030

\section{Introduction}

Colloquially understood, the word "myth" means a misconception about someone or something, which is taken for granted without evidence. A myth is a story about a fact or event embellished with untrue yet colourful details (SŁOWNIK JęZYKA POLSKIEGO 1979). As humans tend to create myths for almost all aspects of their lives, it is hardly surprising that the concept and practice of valuation, and particularly its fundamental element - market value - are not free of them either. It is quite natural given that market value, one of the most intricate in economic theory, is also very complicated in valuation methodology and practice. Unfortunately, many authors of textbooks, lecturers and practitioners find it sufficient to cite the legal definition of market value, assuming that its concept is intuitively obvious.

Using the definition of market value without trying to probe into its deeper meaning bears negative consequences for the practice of valuation and undermines the credibility of valuation results. It also leads to many misinterpretations of value and paves the way for a wide array of myths.

\section{Research aim and method}

Various studies have shown that the property valuation methodology has not striven enough to understand and explain the intricacy of the concept of property value (CANNONE et al. 2005, 
KUCHARSKA-STASIAK 2012). It has been found that valuers tend to apply the readily available definitions of value without looking into its nature, to concentrate too much on the descriptions of methods and techniques while missing vital "whys", and to seek retreat in the passive citation of the pertinent legislation. The lack of understanding or misinterpretation of value results in inaccurate valuations, the same property having considerably different valuations and damage to the prestige of the property valuer profession.

This study was undertaken to critically evaluate different views on the property value. Two research methods were used: a literature review and an observation method that the author employed during her teaching activity and entry exams for the profession of property valuers.

\section{Myths and counterarguments}

Three areas conducive to the emergence of myths have been identified: the interpretation of property market value, the process of arriving at property market value and the interpretation of valuation results.

\subsection{Interpretation of property market value}

\section{Myth 1: Market value is a legal category}

The property market value has been formally defined by the International Valuation Standards (IVS), the European Valuation Standards (EVS), the EU documents and in the Polish Real Property Management Act (RPMA).

Because in Poland the property market value is defined by law, Polish property valuers have developed the belief, upheld by the legal community, that it should be understood in legal terms. This approach is apparently convenient, as it involves a false illusion of security and makes considering the economic aspects of value and the economic determinants of valuation unnecessary.

In fact, value is an economic category, which implies that it should be considered in the context of economic theories rather than taken literally. Its definition and interpretation arise from the achievements of economics: its purpose is to objectivise the market and its nature is external rather than internal. The definition of value that we use today is certainly conventional, a product of centuries-old debates on its nature that are very likely to continue into the future. The intricacy of value has led Western European value theorists to the conclusion that it is not possible to present its general legal concept (CANNONE et al. 2005). When legislation is only a context to valuation, valuers should refer to the rules of economics and should interpret property market value from the market perspective. The economic origin of value was emphasised by the 2005 IVS that presented property value as an economic notion reflecting the market's opinion on the benefits of purchasing a given good or service as on the valuation date (IVS 2005, p. 42).

\section{Myth 2: A property is worth as much as a buyer will pay}

This myth refers to the subjectivist approach to value measurement, credited to the Austrian school of economics, which allows for psychological aspects of value including consumer behaviour. According to the approach, the basis of a product's value is its utility and not the inputs used to make it, so the measure of value is the degree to which a product meets customer's expectations. MĄCZYŃSKA (2011) perceives this as the manifestation of the dominance of "externality" in value measurement, the marginalization of "internal" essentials of the process, and the superiority of external opinions that become "... characteristic of our times, where sham and appearances prevail over deep reflection and insightfulness". As result, in the opinion of many people not only a real property but also „...an enterprise is only worth as much as a potential buyer would pay" (MĄCZYŃSKA 2011).

The purposes of valuation conflict with the subjectivist approach, as they require the objectivization of the market which cannot be done unless the collective behaviour of market participants is understood. An objective property market value is one that is widely accepted and independent of individuals' arbitrary judgments (STANKIEWICZ 2000, pp. 160-161). The methodology of valuation distinguishes between a market value that objectivizes the market and an investment (individual) value.

\section{Myth 3: A market value fully objectivizes the market}

In economics, the full objectivization of market phenomena is never achieved. Being a social science, economics has a problem with the precise measurement of economic phenomena, which are not only 
hard to extract and scale down to laboratory dimensions, but also do not repeat very often. The difficulty in acquiring market data and capturing the collective behaviors of market participants has two sources. One is the researcher having to make judgments on the analyzed phenomena, and the other is the researcher's attitude. Knowing that observation as a research method only allows some characteristics and relations between objects to be identified, with many others going unobserved, a researcher may become fearful of making the mistake of superficial and partial observations (STACHAK 2003 , p. 163) and consequently select data matching the baseline assumptions and reject all others. The fact that arriving at objective values is a problem has been confirmed by psychologists who have concluded that the process of cognition involves the construction of mental images and events based on the interpretation and inferences drawn from the received stimuli. There is a gap between how things are perceived and what they really are (PISKORZ, ZALEŚKIEWICZ 2003, pp. 116-118). Even the best knowledge of the market and having a professional determine the value are not enough to produce a valuation that will be fully objective. The more unique the legal and physical characteristics of a property are, the fewer transactions there are and the less transparent and mature the market is, the more difficult the objectivization of value is (RATTERMANN 2014). The awareness of this causes that valuers conclude their reports with the following statement "In my opinion, the property's value is ....". Therefore, regardless of how active and mature a property market is, clients pay for the valuer's subjective interpretation of scientifically objective analysis and calculations (GILBERTSON 2001).

\section{Myth 4: A real property has only one market value on the valuation date regardless of the purpose} of valuation

Property valuations are undertaken for many purposes. In each case appropriate assumptions about the state of the property and the market must be developed, on which the valuation result will depend. For instance, a property valued by the same professional may have different values when appraised for different purposes (an inheritance claim and sale), because the assumptions about the property's state of repair and utility and the market activity have to match the purpose of the valuation. Different estimates may also be produced when a property is valued assuming the same state of repair and market activity for the purposes of sale or as a loan collateral because, in both cases, special diligence is required. To avoid misunderstandings, valuers conclude their reports with a statement that they should not be used for any other purpose but that for which they were commissioned.

\subsection{Valuation}

\section{Myth 5: The choice made by the property determines the approach to the valuation}

Many valuers endorse the belief that the valuation method should correspond to the property's existing use. This implies that a comparative method should be applied to value residential properties, an income method is appropriate for commercial properties, etc. However, this is not so.

The valuation approach, method and technique must be selected based on the purpose of the valuation, the available market data and, most importantly, buyers' motivations (or, more broadly, the culture prevailing in a market segment that decides which property value determinants are perceived as crucial). Therefore, the comparative approach is not the only one by means of which residential properties can be valued. It is certainly appropriate for residential properties that are sought for their utility, but in a market for income-generating properties, the income approach is the right one. It is noteworthy that property use has not been included in the range of statutory criteria to be considered by valuers selecting a valuation approach, method and technique (Art. 154.1 RPMA 1997).

\section{Myth 6: The comparative approach and the income approach produce the market value}

There is a widespread opinion among valuers that, by using the comparative approach or the income approach, they arrive at the property market value. This conviction derives from the literary understanding of art. 152.3 RPMA (1997):

"When the comparative approach or the income approach is used, the market value of a property is determined".

The above wording is not equivalent to: "The application of the comparative approach or the income approach results in the determination of a market value". The legislature rightly assumed that both approaches are a form of market analysis enhancing the valuation process. As no legal restrictions 


\section{$\$$ sciendo}

have been imposed limiting their use to the market value, they can also be employed when nonmarket values are sought, e.g. an individual value. Accordingly, the very use of the approaches is not sufficient to believe that a property market value has been obtained, because the latter requires the use of appropriate data representing the collective behavior of market participants. That not all market data qualify as evidence for valuation purposes is referred to in the next part of art. 152.3: "If the existing conditions prevent the use of the comparative or income approach, the mixed approach shall be used to arrive at a market value" (RPMA 1997).

\section{Myth 7: The property valuation model is a demand-supply model}

Property prices and consequently their values depend on market supply and demand. When supply increases while demand remains constant property, values fall, whereas rising demand for properties under constant supply drives their prices upward. Because a property value is determined as on the valuation date, a market data analysis should not cover a long period (the principle of anticipation). In the short term, an increase in the supply of some specific type of property is not very likely. Even if EVANS (2004, III) is right about supply being, in the short term, a flow rather than a constant, such adjustment in supply would not be significant. According to Marshall, the importance of demand tends to increase in shorter periods, but in longer periods, supply becomes more important (LANDRETH, COLONDER 2005, p. 301). Because valuers determine a property's market value as of the valuation day, its level is primarily shaped by demand (WYCENA NIERUCHOMOŚCI... 2000, p. 59). Therefore, the model of valuation is generally deemed a demand model.

\section{Myth 8: A market value includes future market changes}

The value of a real property is a future value, so it should account for the utility or income-generating capacity that the property will have in the future. Yet, a prudent and knowledgeable buyer (as the market value definition requires) estimates the future benefits of owning the property based on the present market situation, meaning that valuers have to use data from the near past.

This mechanism influences the application of the discounted cash flow technique (DCF) that uses "cash flow forecasts". A cash flow forecast may focus on changes in the property condition or consider market changes arising from variations in supply and demand. In the first case, market changes are included in the rate of return (a measure of risk) and not in the cash flow. In the second case, they are reflected in the cash flow, which never stabilizes because of market volatility. The first approach is representative of the British school, which uses the implicit cash flows to account for changes in a property, while the second approach is typical of the US school, which is believed to be the most market-oriented and reflects market changes in the explicit cash flows.

As a consequence of the Polish property valuation methodology referring to the British school, the first definition of a "cash flow forecast" has been adopted. Accordingly, it is assumed that, in the forecast period, a cash flow may vary as a result of repairs, improvements, a likely need to partially or completely change the current use of the property, and extension or demolition works necessary to free the site for redevelopment. The forecast covers a period that a property needs to reach the market level of profitability. After the forecast period, cash flow steadies at the market level as noted on the valuation date.

In the US income approach, it is the changing condition of the property and extrapolation of the current market trends that cause cash flows to vary. Accordingly, US valuers tend to use a discounted cash-flow technique assuming that cash flows also vary in the post-forecast period. This assumption is consequential, because it requires that the discount rate and the capitalization rate in the residual value always be different. To discount future cash flows, future rather than past discount rates have to be used (WYCENA NIERUCHOMOŚCI... 2000, p. 309).

\section{Myth 9: The market value is an average value}

The definitions of the market value state that "the market value is the most probable price". A property market value is frequently understood as an average price noted in the market over the observation period.

This interpretation is ungrounded, because an average value fails to account for the competitive position of a property in the market. It also challenges the definition of market value, according to which parties to a transaction must be independent, willing, prudent, knowledgeable and must act without compulsion. To comply with the definition, valuers must clean the market data of irregular, 
noise-generating inputs derived from market bargains or indicating amateurish or irrational behavior of parties, as they are very likely to be inconsistent with the foundations of the market value definition. In most cases, relatively low property prices are due to the parties being connected in some way, compulsion, imprudence or a lack of market knowledge. The typical causes of relatively high prices include special contractual arrangements between the parties (deferred payment), an urgent need to buy, buying on an impulse, etc.

Although all valuation approaches and methods need data cleaning, it is all too often the case that, when the paired comparison method is used, valuers present only three or four arbitrarily selected pieces of market information rather than their whole set. Likewise, when the average price adjustment method requiring ten-odd pieces of market information is employed, eleven or twelve inputs are utilised rather than the full set of transaction data.

The use of irregular values constitutes a breach of the Ordinance of the Council of Ministers of 21 September 2004 on the Appraisal of Real Estate and the Preparation of Property Valuation Report (ORDINANCE OF... 2004) stating that:

\$3.2. "The determination of a property's value shall be preceded by the analysis of the real estate market, particularly of property prices, rent rates and the terms and conditions of transactions".

$\$ 4.3$."When the paired comparison method is employed, the valued property with known characteristics shall be successively compared with similar properties that have been transacted in the market and so have known transaction prices, terms and conditions of transactions, and characteristics".

\$4.4."The average price adjustment method requires that comparisons be made using at least ten-odd similar properties which have been transacted in the market and so have known transaction prices, terms and conditions of transactions and characteristics."

Although similar provisions applying to the income approach have not been established, it can be inferred by analogy that the terms and conditions of transactions should also be considered when market rent rates are studied ( $\$ 3.2$ of the ORDINANCE OF... 2004). It can also be assumed that the rule is also valid with respect to calculations of market vacancy rates, operating expenses and the market rates of return.

\section{Myth 10: A property market value is a transaction price}

A market value understood as the most probable price is actually a price hypothesis, formulated $e x$ post and encapsulating general observations based on inadequate and unrepresentative facts. A hypothesis is a tentative statement as its truthfulness is yet to be proven. Its common synonyms are "guess", "supposition" or "conjecture" (STACHAK 2003, p. 89). The value of a property is an estimate and not a price that is certain to be paid (IVS 2017, p. 18). It is a price hypothesis underlain by the assumption that a sufficient period of time has elapsed for the property to be exposed to the market and to negotiate its price. In other words, the appraised property value is valid on its date of issue provided that the date and the date when the purpose of valuation is fulfilled are the same.

In practice, there tends to be a gap between the valuation date and the date when its purpose is fulfilled. A study by RICS has estimated it at 9 months on average (VALUATION AND... 2008). Given this information, it is not surprising that values and transaction prices of properties differ from each other because of market disequilibrium, limited market transparency, the special motivations of the transaction parties, as well as due to market changes affecting property values. The property's value may also change as a result of alterations made to it or new developments in the adjacent area. The difference between the appraised value and the transaction price is known as "valuation accuracy". In the long term, a property's value is fairly consistent with its future price, but in the short term, a difference between them is natural (BROWN, MATYSIAK 2000). The issue of valuation accuracy is frequently studied in countries with mature real estate markets and a longer history of valuation than Poland (BROWN, MATYSIAK 2000, Crosby et al. 2003).

\section{Myth 11: The market value as the most probable price is the highest price}

Land is a scarce resource characterized by fixed total supply and a lack of substitutes. The demand for land as well as for other production factors is called a derived demand, because it is driven by the demand for products and services delivered by utilizing the factors (BEGG et al. 1993). Low price elasticity of demand for land means that an increase in its price causes a less than proportional drop in demand. The inflexibility of land supply means that it does not increase when land prices go up, and when its prices are rising stronger efforts are made to make better use of it. The concept of the 
effective use of assets is fundamental in estimating the values of various goods (KARMIŃSKA 2009), including real property.

The European Valuation Standards of 2016 require that in determining the market value of properties, their highest and best use be considered (EVS 2016, pp. 25-26). The highest and best use is defined as the most probable, physically possible, appropriately supported, legal and financially feasible use ensuring the highest value of the asset (IVS 2007, p. 39). Because valuers examine properties including their legal constraints as on the valuation date, the approach disregards their potential that the market may see in the future.

A property's value that fully reflects its market potential, if there is one (IVS 2016, p. 24), is known as a hope value, i.e. one that the market would pay for a property in the hope that it will be granted an alternative use or a that the possibility of developing the property in a manner that will increase its value over and above that achievable under today's constraints on its development will emerge (EVS 2016, p. 25). The hope value is an expression of rational, most probable expectations of the market (EVS 2016, p. 25). Both the hope value and the highest and best use are determined based on market experiences which may be insufficient to define the best and highest use if it is not yet present in the market. It may happen, however, that a buyer will come up with some new idea that will significantly increase the property's value.

\section{Myth 12: The market value as the most probable price is the lowest price}

Polish valuers are familiar with the notion of property market value understood in terms of the lowest price concept which assumes that, because a market value is defined as the most probable price, the most probable price hypothesis corresponds to the lowest price. This interpretation of value is poles apart from the real behaviour of market participants and from the fact that low market prices are followed by reduction of supply. With low supply, price rises boost supply but discourage potential buyers. Therefore, the most probable price to be paid for a property is a typical price, i.e. one that most market participants would pay.

\section{Myth 13: Every property has a market value for its existing use}

Many authors argue that because of the central role of the "highest and best use" it should be determined before the valuation approach is selected. The fact that the existing use of most properties is also the highest and best use (RATTERMANN 2009, pp. 167-168) does not change the fact that, in some cases, it may fall short of exploiting the properties' full potential and of presenting them as an asset. When a valuer takes the existing use of a property as a valuation basis, the attempt to determine its market value may prove unsuccessful if the use is rare in the market. For instance, placing market value on post-industrial properties may turn out to be difficult if no one wants to use them for production purposes. In such cases, some alternative uses of problematic assets need to considered (RATTERMANN 2009, pp. 157-169).

\section{Myth 14: Automated valuation models produce valid appraisals}

Valuation methods fall into two categories: traditional and advanced. The advanced valuation methods which have been described, inter alia, by KAUKO (2003), KAUKO AND D'AMATO (2004), LORENZ (2006), MooYA (2016), utilize various data analysis methods, including hedonic models, econometric forecasting, intelligent systems, the house price index models, or tax assessed value models. The methods are frequently used to build the increasingly popular automated valuation models (AVM) (GRZESIK 2017).

Notwithstanding the popularity of the AVM models, their merits in the field of valuation are still discussed by theorists and practitioners alike. Some argue that the models are superior to traditional methods, particularly in markets having the characteristics of highly competitive markets (MOOYA 2016 pp. 65-82). Others subject them to broadside criticism. One of AVMs' prominent critics is Dell, who has compared them to a black box with a funnel on top. "You put data the box whirrs and clanks, and out comes the "estimate," which is not an appraisal" (DELL 2004, p. 13 as quoted in: LORENZ 2006, p. 165). The reason for his criticism is AVMs' inability to "... observe the subject, its condition, safety hazards, lot utility, view, traffic conditions, adjacent negative land uses, etc. (AVMs) work poorly for unique properties and for mixed neighbourhoods (and) can err greatly in either direction" (LORENZ 2006, p. 165). It is believed that they fail to produce a market value because "The average price is appraised based on desk review without a field inspection ..." (GRZESIK 2017, p. 39). The widespread view is that AVMs' are more 
appropriate for tax assessment purposes, while traditional methods are superior when single properties are being valued (LORENZ 2006, p. 164) because they are capable of capturing the collective behaviour of market participants who act on their market experience and not on mathematical formulas.

The discussion about AVMs' usefulness in valuing single properties resurfaced with debates over the causes of the financial crisis of 2007-2008. The risk of using AVMs' to value properties for lending purposes was highlighted in the final report of The Committee of Inquiry into the Banking Crisis of 27 January 2016,which was commissioned to determine the causes of systemic crisis in the Irish banking sector (GRZESIK 2017, p. 40). According to The Committee, one of them was the use of "pure" AVM models. Another document that pointed to their low reliability was the report prepared by a renowned law firm in Brussels on behalf of TEGoVa (GRZESIK 2017, pp. 39-41). The use of AVMs for property valuation was also criticised by G. Matysiak, who stated in his report that the European AVM industry was shrouded in mystery and that the accuracy of the models, which are advertised and sold as complex and sophisticated tools, was difficult to verify (EUROPEAN VALUER 2017). The relevance of figures produced by them has not been verified by any independent organization. The European Banking Authority disqualified AVMs as the sole instrument of valuation or of verification of valuation results, also stating that such verification can only be performed by a qualified, independent valuer who has the necessary skills and experience (EUROPEAN VALUER 2017). G. Matysiak also cited one of the AVM suppliers who predicted the popularity of AVMs to grow, particularly regarding the increasing complexity of data and analytics. He did not think likely, though, that AVMs could replace traditional valuations, because the specialist knowledge and understanding of local conditions would also be necessary, likewise field inspections of properties (MATYSIAK 2018).

\subsection{Interpreting valuation results}

\section{Myth 15: Valuation produces a precise, certain value}

"Certainty" is a lack of doubt about some state of affairs that is rarely or almost never experienced in life. The belief of both parties to a valuation engagement, the valuer and the client, that the appraised value is certain and true lacks solid support. A. DAMODARAN (2006), a foremost valuation theorist, has noted that valuations producing exact values do not exist. This implies valuers do not produce market values which are a market phenomenon. What they are responsible for is to examine market data with methods allowing a market value objectivising the market to be identified (MOOYA 2016, p. 46).

The consequence of problems with objectivizing economic phenomena is uncertainty and risk, two inseparable aspects of valuations. It is considered that uncertainty is a real and universal challenge affecting valuations, including the valuation of real property (FRENCH, GABRIELLI 2003).

Damodaran has also found all valuations to be biased, with the direction and magnitude of the bias being directly proportional to who pays and how much the valuer is paid (DAMODARAN 2006). Evidence of the biased nature of valuations can be found in numerous studies investigating national real estate markets, including the Polish market (e.g. WOLWERTON 2000, KUCHARSKA-STASIAK 2014).

Uncertainty inherent in valuations is a major cause of different estimates produced by valuers for the same property. The uncertainty of single valuations translates into uncertainty as to the magnitude of discrepancies between valuations, which are known as a "margin of error" (BROWN, MATYSIAK 2000). Some discrepancies are natural, because transaction prices, market rent rates or the condition properties are never completely certain.

It is reported that the use of AVMs does not make valuation results more certain. Using the US data, G. MATYSIAK (2018) studied the statistical methods and AVM models and found the estimates they produced much outside the boundaries of a reasonable margin of error. For instance, as much as $83 \%$ valuations differed from transaction prices by $+/-20 \%$. In some counties, the difference ranged from $32 \%$ to even 100\% (MATYSIAK 2018).

\section{Conclusion}

The article provides a critical review of 15 myths related to the interpretation of property market value, the process of arriving at property market value and the interpretation of valuation results. The analysis of views on the nature of market value was performed to demonstrate that: (1) a property market value is an economic rather than a legal category; (2) the objectivization of market participants' 


\section{$\$$ sciendo}

behaviors necessary to determine a property market value is never complete; (3) a property has more than one market value on the valuation day; (4)_the valuation approach should selected based on the purpose of the valuation and the availability of market data rather than with respect to the existing use of the property; (5) the valuation model is a demand (investment) model.

Property value is an estimate determined on the valuation date taking account of future benefits expected of the asset. It is the most probable price represented by the price hypothesis prevailing in the market. As such, it is neither an average value nor a lowest or highest market value. Some properties may not have a market value for their present use.

The weakness of the automated valuation models (AVM) is that they fail to account for properties' special characteristics and the way market participants think.

All valuations and their results are uncertain to a degree. Uncertainty of valuations is independent of whether traditional or automated valuation methods are used.

\section{References}

BEGG D., FisCHER S., DORnBusch R., 1993, Ekonomia, vol. 1, PWE, Warszawa. (Economy),

BROWN G. R., MATYSIAK G., 2000, Real Estate Investment. A Capital Market Approach, Financial Times, Prentice Hall,

CANNONE J., MAcdonald R. J., ÖZDILEK U., 2005, Valuation Without Value Theory: a North American "Appraisal", March 2005,

Crosby N., Devancy S., Key T., MAtysiaK G., 2003, Valuation Accuracy: Reconciling the Timing of the Valuation and Sale, ERES, Helsinki,

European Valuer, TEGoVA, 2017 Issue No. 8,

Damodaran A., 2006, Valuation Approaches and Metrics: A Survey of the Theory and Evidence, Stern School of Business.,

(EVS) European Valuation Standards, 2016, Eighth edition, TEGoVA,

Evans A. W., 2004, Economics, Real Estate and Supply of Land, Blackwell Publishing,

FRENCH N., GABRIELLI L., 2003, The Uncertainty of Valuation, ERES, Helsinki,

GILBERTSON B., 2001, Valuation or Appraisal: Art or Science?, Global Real Estate Now, Spring 2001,

GRZESIK K., 2017, Zautomatyzowane modele wyceny (AVM) dla celów zabezpieczenia wierzytelności kredytowej (Automated Valuation Model for the Purpose of Mortgage Security), Rzeczoznawca Majątkowy (Real Estate Valuer), No. 1 (93),

(IVS 2017) International Valuation Standards, IVSC, London 2017,

(IVS 2005) Międzynarodowe Standardy Wyceny (International Valuation Standards), 2005, IVSC, PFSRM, Warsaw,

KAUKO T., 2003, Residential Property Value and Locational Externalities, Journal of Property Investment and Finance, Vol. 21, No. 3, pp. 250-270,

Kauko T., D'Amato M., 2004, Mass Appraisal Valuation Methodologies: Between Orthodoxy and Heresy, $11^{\text {th }}$ European Real Estate Society Conference, ERES 2004,

KARMIŃSKA A., 2009, Wartość ekonomiczna w systemie informacyjnym rachunkowości finansowej (The economic value in the financial accounting information system), Difin,

KUCHARSKA-STASIAK E., 2012. Wycena bez wartości (Valuation Without Value), Studia i Materiały Towarzystwa Naukowego Nieruchomości (Studies and Materials of the Polish Real Estate Scientific Society), Olsztyn, Volume 20, No. 2, pp. 5-20,

KUCHARSKA-STASIAK E., 2014, Behawioralne aspekty w wycenie nieruchomości (Behavioral Aspects in Property Valuation, Management and Finance), Zarządzanie i Finanse (Management and Finances), No. 4, pp. 247-261,

LANDRETH H., COLONDER D. C., 2005, Historia myśli ekonomicznej (History of Economic Thought), Wydawnictwo Naukowe PWN, Warsaw,

LorenZ D. P., 2006, The Application of Sustainable Development Principles to the Theory and Practice of Property Valuation, Universitätsverlag Karlsruhe,

MATYSIAK G., 2018, An Overview of Statistical Valuation Models and the Accuracy of Automated Valuation Models (AVMs), European Valuation Conference: Statistical Methods of Valuation - Are they Legal? 27th February 2018,

MĄCZYŃSKA E., 2011, Gdy stuga staje się panem, czyli dysfunkcje pomiaru wartości biznesu i wyników działalności gospodarczej (When a Servant Becomes a Master, the Dysfunctions of Measuring Business Value and Business Performance), Finanse, Rynki Finansowe, Ubezpieczenia (Finance, Financial 
Markets, Insurance), No. 37, pp. 103-120,

Mooy M. M., 2016, Real Estate Valuation Theory. A Critical Appraisal, Springer,

PISKORZ Z., ZALEŚKIEWICZ T., 2003, Psychologia umystu (Psychology of the mind), GWP, Sopot,

RATTERMANN M. R., 2014, The Student Handbook to the Appraisal of Real Estate, $13^{\text {th }}$ Edition, Appraisal Institute, Chicago,

RatTeRmann M. R., 2009, The Student Handbook to the Appraisal of Real Estate, Appraisal Institute, Chicago,

STACHAK S., 2003, Podstawy metodologii nauk ekonomicznych, Książka i Wiedza. (Basics of economic science methodology),

STANKIEWICZ W., 2000, Historia myśli ekonomicznej (History of Economic Thought), PWE, Warsaw.

Stownik Jezzka Polskiego, 1979, PWN Warsaw. (Polish dictionary),

Valuation and Sale Price Report, 2008, RICS, IPD,

Wolverton M. L., 2000, Self-Perception of the Role of the Appraiser: Objective Opinions or Price Validations?, The Appraisal Journal, July 2000,

Wycena nieruchomości. Wydanie Polskie (Property Valuation. Polish Edition), 2000, Warsaw.

\section{Legal acts}

Rozporządzenie Rady Ministrów z dnia 21 września 2004 roku w sprawie wyceny nieruchomości $i$ sporzadzania operatu szacunkowego (Dz. U. $2004 \mathrm{nr}$ 207, poz. 2109) (Ordinance of the Council of Ministers of 21 September 2004 on the Appraisal of Real Estate and the Preparation of Property Valuation Report, Journal of Laws, 2004, No. 207, item 2109, as amended),

(RPMA 1997) Ustawa z dnia 21 sierpnia 1997 roku o gospodarce nieruchomościami, Dz. U. 2016, poz. 2147, z późn. zm. (Act of 21 August 1997 on real estate management, Journal of Laws, 2017, item 2147, as amended). 